Volume 3 • Nomor 1 • Oktober 2019

Pege (Hal.) : $99-106$

(C) Universitas Pamulang

JL.Surya Kencana No.1 Pamulang, Tangerang Selatan - Banten

Telp. (021) 7412566, Fax (021) 7412491

website. : Email : jurnalmarketing.unpam@gmail.com

\title{
Pengaruh Kualitas Pelayanan Terhadap Kepuasan Pelanggan Pada CV. Jaya Motor Bekasi
}

\author{
Arif Rahman ${ }^{1}$ Slamet Heri Winarno ${ }^{2}$ \\ Universitas Bina Sarana Informatika, : arifrahman2809@gmail.com
}

\begin{abstract}
Abstrak. Tujuan dari penelitian ini adalah untuk mengetahui tanggapan pengguna jasa (customer) berupa tingkat kepuasan pada pelayanan jasa service sepeda motor di CV Jaya Motor. Penelitian dilakukan dengan menggunakan metode kuantitatif dengan teknik analisa statistik regresi korelasi dengan menggunakan sampel responden pemilik sepeda motor yang selalu melakukan jasa service di CV Jaya Motor. Hasil penelitian menunjukkan terdapat pengaruh yang positif dan signifikan antara variabel pelayanan dan kepuasan customer sebesar 0,766 . Hasil pengujian determinan juga memperlihatkan bahwa 58,7\% kepuasan customer CV Jaya Motor di pengaruhi oleh pelayanan yang diberikan, sedangkan $41,3 \%$ dipengaruhi oleh faktor lain, sedangkan persamaan regresi yang dibentuk yaitu $Y=8,630+0,868(X)$.
\end{abstract}

\section{Keywords: Kualitas Pelayanan; Kepuasan Pelanggan}

Abstract. The purpose of this research is to know the response of service users (customer) in the form of satisfaction level in motorcycle service service in CV Jaya Motor. Research conducted using quantitative methods with statistical analysis techniques of regression correlation by using samples of respondents of motorcycle owners who always perform service services in CV Jaya Motor. The results showed a positive and significant influence between service variables and customer satisfaction of 0.766 . The results of the test determinant also showed that $58.7 \%$ of customer satisfaction of CV Jaya Motor is influenced by the service provided, while $41.3 \%$ influenced by other factors, while the regression equation formed is $Y=8.630+0,868(X)$

\section{Key words: Service Quality; Customer Satisfaction}

\section{A. PENDAHULUAN}

CV Jaya Motor merupakan salah satu penyedia jasa pelayanan service kendaraan motor yang selalu memberikan pelayanan yang baik pada kegiatan usahanya. Berbekal slogan pelanggan adalah mitra kami, CV Jaya Motor terus meningkatkan sisi pelayanannya. Meningkatnya jumlah pemakai kendaraan bermotor akhir-akhir ini membuka peluang bagi CV Jaya Motor untuk memberikan pelayanan dalam jasa service motor. Dukungan teknisiteknisi yang handal serta peralatan yang modern, menjadikan pelayanan jasa service di CV Jaya Motor menjadi tujuan bagi para pelanggannya.

Inti dari proses pemberian pelayanan adalah terciptanya tingkat kepuasan bagi konsumen. Hal ini yang menjadi main core business CV Jaya Motor dalam menjalankan usahanya. Semakin banyak konsumen yang puas dengan layanan yang diberikan, tentunya akan menambah jumlah konsumen dan profit perusahaan. Hal ini menarik untuk diteliti tentang bagaimana membangun kepuasan konsumen terhadap pelayanan yang diberikan 
kepadanya, sehingga akan diperoleh gambaran tingkat keberhasilan perusahaan dalam menjalankan strategi pelayanannya.

Rumusan Masalah : 1. Bagaimana kualitas pelayanan yang diberikan oleh CV Jaya Motor Bekasi terhadap pelanggan? 2. Bagaimana tingkat kepuasan yang dirasakan oleh pelanggan CV Jaya Motor Bekasi? 3. Bagaimana pengaruh kualitas pelayanan terhadap kepuasan pelanggan pada CV Jaya Motor Bekasi?

Tujuan Penelitian: 1. Untuk mengetahui kualitas pelayanan yang diberikan oleh CV Jaya Motor Bekasi. 2. Untuk menggambarkan tingkat kepuasan pelanggan pada CV Jaya Motor Bekasi. 3. Untuk menjelaskan pengaruh kualitas pelayanan terhadap kepuasan pelanggan pada CV Jaya Motor Bekasi.

\section{B. KAJIAN LITERATUR}

Kualitas Pelayanan

Usaha untuk memuaskan seseorang atau pihak-pihak tertentu dapat dilakukan dengan serangkaian kegiatan yang dinilai bermanfaat yang diberikan oleh orang lain sesuai dengan jenis usahanya (Rangkuti (2017:64).

Di sisi lain Gronroos dalam Winarno (2018) mengungkapkan pelayanan berarti bentuk interaksi antara pemberi jasa kepada konsumennya dalam memecahkan masalah yang dihadapi secara tidak nyata sebagai wujud timbal balik yang saling menguntungkan diantara keduanya. Unsur utama yang menjadi dasar pasa sebuah pelayanan antara lain: (1) menjunjung nilai sikap (attitude); (2) mengedepankan unsur perhatian (attention); (3) fokus pada tindakan (action) (Rangkuti, 2017:254).

Kepuasan Pelanggan

Menurut Kotler \& Keller (2012:194): "Satisfaction is the function of the closeness between expectations and the product's perceived performance. If performance falls short of expectations, the consumer is dissapointed; if it meets expectations, the consumer is satisfied; if it exceeds expectations, the consumer is delighted".

Menurut Schiffman dalam Rangkuti (2017:80) menyatakan "Kepuasan pelanggan merupakan perasaan seseorang terhadap kinerja dari suatu produk atau jasa yang dibandingkan dengan harapannya".

Menurut Lovelock dalam Rangkuti (2017:80) menyatakan "Kepuasan pelanggan merupakan keadaan emosional, reaksi paska pembelian mereka yang dapat berupa kemarahan, ketidakpuasan, kejengkelan, kegembiraan atau kesenangan

\section{METODOLOGI PENELITIAN}

Penelitian ini bersifat deskriptif kausalitas yang menerangkan tentang hubungan antar dua variabel atau lebih yang saling berpengaruh satu dengan yang lain. Metode penelitian yang digunakan antara lain :

Metode Observasi : Menggumpulkan data yang berhubungan dengan rumusan masalah dengan cara melihat dan mengamati langsung aspek-aspek yang berhubungan dengan pelayanan pelanggan dan kepuasan pelanggan pada CV Jaya Motor Bekasi.

Metode Dokumentasi : Memperoleh data pelengkap dengan cara melampirkan dokumendokumen pendukung yang terkait dengan objek yang diteliti.

Metode Kuesioner : Mengumpulkan data dengan cara memberikan kuesioner kepada pelanggan yang datang untuk mengisinya untuk mengetahui persepsi tentang pelayanan yang diberikan. 
Teknik pengumpulan data menggunakan data sample responden. Teknik yang digunakan yaitu simple random sampling, responden ditentukan secara acak terhadap konsumen yang datang ke CV Jaya Motor untuk service sepeda motor yaitu sebanyak 50 orang yang dengan tidak memandang klasifikasi tertentu.s

\section{HASIL DAN PEMBAHASAN}

Berdasarkan olahan data kesioner dapat dijelaskan terlihat bahwa responden yang dijadikan objek penelitian lebih banyak laki-laki dibanding perempuan. Prosentase responden laki-laki sebesar $90 \%$, sedangkan untuk responden perempuan sebanyak $10 \%$.

Karakteristik Responden Berdasarkan Usia

Berdasarkan olahan data untuk karakteristik responden berdasarkan usia dibagi berdasarkan rentang umur 17-25 tahun, 26-35 tahun, 36-45 tahun, 46-55 tahun, >55 tahun, dimana dapat digambarkan dalam bentuk prosentase untuk responden yang berusia 17-25 tahun dengan prosentase 34\%, 26-35 tahun dengan prosentase 42\%, 36-45 tahun dengan prosentase $20 \%$, 46-55 tahun dengan prosentase $4 \%$.

Karakteristik Responden Berdasarkan Pekerjaan

Berdasarkan olahan data untuk karakteristik responden berdasarkan pekerjaan, yakni pelajar dengan prosentase $14 \%$, pegawai negeri sebesar $4 \%$, pegawai swasta sebesar $58 \%$, wiraswasta sebesar $18 \%$, pedagang sebesar $2 \%$, buruh sebesar $4 \%$.

Karakteristik Responden Berdasarkan Frekuensi Berkunjung

Berdasarkan olahan data untuk karakteristik responden berdasarkan frekuensi berkunjung dapat dilihat dari berapa banyak berkunjung, yaitu $1 x$ dalam sebulan sebesar $72 \%$, 2x dalam sebulan sebesar $16 \%$ dan $>2 x$ dalam sebulan sebesar $12 \%$.

Uji Instrumen Penelitian

Tabel 1. Uji Validitas Variabel Pelayanan

\begin{tabular}{ccccc}
\hline & $\begin{array}{c}\text { Scale Mean if } \\
\text { Item Deleted }\end{array}$ & $\begin{array}{c}\text { Scale Variance } \\
\text { if Item Deleted }\end{array}$ & $\begin{array}{c}\text { Corrected } \\
\text { Item-Total } \\
\text { Correlation }\end{array}$ & $\begin{array}{c}\text { Cronbach's } \\
\text { Alpha if Item } \\
\text { Deleted }\end{array}$ \\
\hline V1 & 59.34 & 26.107 & .457 & .889 \\
\hline V2 & 59.32 & 25.691 & .396 & .892 \\
\hline V3 & 59.20 & 24.653 & .567 & .885 \\
\hline V4 & 59.24 & 24.962 & .572 & .885 \\
\hline V5 & 59.18 & 24.314 & .669 & .881 \\
V6 & 59.06 & 24.792 & .643 & .882 \\
\hline V7 & 59.26 & 25.298 & .438 & .890 \\
\hline V8 & 59.32 & 24.998 & .525 & .887 \\
\hline V9 & 59.28 & 23.920 & .702 & .879 \\
\hline V10 & 59.40 & 24.245 & .600 & .883 \\
\hline V11 & 59.38 & 23.832 & .754 & .877 \\
\hline V12 & 59.22 & 24.991 & .513 & .887 \\
\hline V13 & 59.10 & 24.663 & .681 & .881 \\
\hline V14 & 59.24 & 24.513 & .533 & .887 \\
\hline V15 & 59.46 & 25.070 & .435 & .891 \\
\hline
\end{tabular}

Sumber : Data diolah 
Berdasarkan data pada tabel 1 tersebut dapat dideskripsikan bahwa nilai total korelasi (rhitung) untuk setiap butir pernyataan lebih besar dibandingkan nilai pada rtabel, sehingga seluruh butir pernyataan pada instrumen variabel pelayanan dinyatakan valid.

Tabel 2. Uji Validitas Variabel Kepuasan Pelanggan

\begin{tabular}{ccccc}
\hline & $\begin{array}{c}\text { Scale Mean if } \\
\text { Item Deleted }\end{array}$ & Scale Variance & $\begin{array}{c}\text { Corrected } \\
\text { item-Total }\end{array}$ & $\begin{array}{c}\text { Cronbach's } \\
\text { Alpha if Item } \\
\text { Deleted }\end{array}$ \\
\hline V1 & 59.54 & 31.151 & .791 & .920 \\
\hline V2 & 59.50 & 31.439 & .770 & .921 \\
\hline V3 & 59.44 & 31.966 & .642 & .924 \\
\hline V4 & 59.80 & 31.061 & .606 & .926 \\
\hline V5 & 59.46 & 31.437 & .743 & .921 \\
\hline V6 & 59.60 & 32.245 & .487 & .930 \\
\hline V7 & 59.58 & 32.412 & .602 & .925 \\
\hline V8 & 59.54 & 31.845 & .670 & .924 \\
\hline V9 & 59.46 & 32.131 & .678 & .923 \\
\hline V10 & 59.40 & 31.265 & .805 & .920 \\
\hline V11 & 59.46 & 31.764 & .637 & .924 \\
\hline V12 & 59.30 & 31.480 & .738 & .922 \\
\hline V13 & 59.72 & 31.267 & .578 & .927 \\
\hline V14 & 59.50 & 31.847 & .696 & .923 \\
\hline V15 & 59.34 & 33.004 & .526 & .927 \\
\hline & & & & \\
\hline
\end{tabular}

Sumber: Data diolah

Berdasarkan pada tabel 2 tersebut dapat disimpulkan bahwa nilai total korelasi $\left(r_{\text {hitung }}\right)$ untuk setiap butir pernyataan memiliki nilai lebih besar jika dibandingkan dengan nilai pada $r_{\text {tabel, }}$, sehingga seluruh butir pernyataan pada instrumen variabel kepuasan pelanggan dinyatakan valid

Uji Reliabiliitas Instrumen Penelitian 
ISSN NO. (PRINT) 2598-0823, (ONLINE) 2598-2893

Tabel 3. Uji Reliabilitas Kualitas Pelayanan

Sumber: Data diolah

\begin{tabular}{cc}
\hline Cronbach's Alpha & N of Items \\
\hline .892 & 15 \\
\hline
\end{tabular}

Sumber: Data diolah

Hasil Perhitungan pada table 3 menunjukkan nilai Cronbach's Alpha (CA) untuk variabel pelayanan sebesar 0,892. Menurut Sekaran (Priyatno, 2014:64) "Apabila CA > 0,6 dapat dikatakan reliabel, sedangkan $\mathrm{CA}<0,6$ dapat dikatakan tidak reliabel dan penelitian tidak bisa dilanjutkan". Dapat dikatakan bahwa nilai CA $>0,6$ dan butir-butir pernyataan pada variabel Pelayanan dinyatakan Reliabel.

Tabel 4. Uji Reliabilitas Kepuasan Pelanggan

\begin{tabular}{cc}
\hline Cronbach's Alpha & N of Items \\
\hline .929 & 15 \\
\hline
\end{tabular}

Sumber: Data diolah

Hasil tabel reliabilitas terhadap butir penyataan kepuasaan menunjukkan nilai $C A>0,6$ sehingga dapat diklasifikasikan Reliabel.

Uji Koefisien Korelasi

Tabel 5. Uji Koefisien Korelasi

\begin{tabular}{|c|c|c|c|}
\hline & & V2 & V1 \\
\hline \multirow{2}{*}{$\begin{array}{l}\text { Pearson } \\
\text { Correlation }\end{array}$} & V2 & 1.000 & .766 \\
\hline & V1 & .766 & 1.000 \\
\hline \multirow[t]{2}{*}{ Sig. (1-tailed) } & $v 2$ & - & .000 \\
\hline & V1 & .000 & - \\
\hline \multirow[t]{2}{*}{$N$} & V2 & 50 & 50 \\
\hline & $V 1$ & 50 & 50 \\
\hline
\end{tabular}

Sumber: Data diolah

Berdasarkan hasil perhitungan pada tabel 5 tersebut dapat disimpulkan bahwa nilai signifikan sebesar 0,000. "Apabila nilai signifikan $<0,05$ maka terdapat hubungan antara pelayanan terhadap kepuasan pelanggan, bila nilai signifikan > 0,05 maka tidak terdapat hubungan antara pelayanan terhadap kepuasan pelanggan" Santoso (2013:265). Hasil perhitungan mengindikasikan nilai signifikan 0,000 0,05 sehingga Ha diterima dan Ho ditolak, terdapat 
ISSN NO. (PRINT) 2598-0823, (ONLINE) 2598-2893

hubungan antara pelayanan terhadap kepuasan pelanggan dengan tingkat hubungan yang kuat yaitu sebesar 0,766.

Uji Koefisien Determinasi

Tabel 6. Uji Determinasi

\begin{tabular}{|c|c|c|c|c|c|c|}
\hline \multirow{2}{*}{\multicolumn{2}{|c|}{ Model }} & \multicolumn{2}{|l|}{ Sum of } & \multicolumn{2}{|l|}{ Mean } & \multirow[b]{2}{*}{ Sig. } \\
\hline & & Squares & Df & Square & $\mathrm{F}$ & \\
\hline \multirow[t]{3}{*}{1} & Regression & 1043.557 & 1 & 1043.557 & 68.284 & $.000^{\mathrm{a}}$ \\
\hline & Residual & 733.563 & 48 & 15.283 & & \\
\hline & Total & 1777.120 & 49 & & & \\
\hline
\end{tabular}

Sumber: Data diolah

Menurut Santoso (2013:285) “Jika signifikan > 0,05 maka Ho diterima, bila signifikan $<0,05$ maka Ho ditolak". Berdasarkan tabel di atas dapat diketahui nilai signifikansi sebesar 0,000 $<0,05$ sehingga $\mathrm{Ha}$ diterima dan $\mathrm{Ho}$ ditolak, dengan kata lain terdapat pengaruh antara pelayanan terhadap kepuasan pelanggan.

Tabel 7. Uji Koefisien Determinasi

\begin{tabular}{|c|c|c|c|c|c|c|c|c|c|}
\hline & & & & Std. & & Chans & e Stá & stics & \\
\hline & & $\mathrm{R}$ & Adjusted & Error of & $\mathrm{R}$ & $\mathrm{F}$ & & & \\
\hline & & Squar & $\mathrm{R}$ & the & Square & Chang & & & Sig. $F$ \\
\hline Model & $\mathrm{R}$ & e & Square & Estimate & Change & e & df1 & $\mathrm{df} 2$ & Change \\
\hline 1 & $.766^{a}$ & .587 & .579 & 3.909 & .587 & 68.284 & 1 & 48 & .000 \\
\hline
\end{tabular}

Sumber: Data diolah

Berdasarkan hasil perhitungan statistik diperoleh nilai $R$ Square sebesar 0,587, mengindikasikan pelayanan yang diberikan CV Jaya Motor dapat berpengaruh terhadap kepuasan pelanggan sebesar $58,7 \%$ dan sisanya sebesar $41,3 \%$ dipengaruhi oleh faktorfaktor yang harus diperhatikan seperti, pemberitahuan promosi, tata ruang atau lay out, citra organisasi dan budaya kerja organisasi.

Uji Persamaan Regresi 
Tabel 8. Uji Persamaan Regresi

Unstandardized Standardized

Coefficients Coefficients

\begin{tabular}{|c|c|c|c|c|c|}
\hline \multirow[b]{2}{*}{ Model } & \multicolumn{3}{|c|}{ Std. } & \multirow[b]{2}{*}{$\mathrm{T}$} & \multirow[b]{2}{*}{ Sig. } \\
\hline & B & Error & Beta & & \\
\hline $\begin{array}{cl}1 \text { (Constant } \\
\text { ) }\end{array}$ & 8.630 & 6.694 & & 1.289 & .204 \\
\hline V1 & .868 & .105 & .766 & 8.263 & .000 \\
\hline
\end{tabular}

Sumber: Data diolah

Hasil hitung tabel nilai signifikan sebesar $0,000<0,05$ dan Ha diterima sebagai akibatnya persamaan regresi dianggap signifikan. Bentuk dari persamaan regresi dari hubungan antar dua variabel yaitu $Y=8,630+0,868(X)$.

Di mana Pelayanan $(X)$ dan Kepuasan Pelanggan $(Y)$ dapat dianalisa sebagai berikut: nilai konstanta sebesar 8,630 artinya apabila pengaruh pelayanan 0 maka kepuasan pelanggan adalah 8,630. Dengan kata lain kepuasan pelanggan sudah ada 8,630 tanpa dipengaruhi oleh adanya pelayanan. Nilai koefisien pelayanan sebesar 0,868 artinya untuk setiap kenaikan satu-satuan $X$ akan meningkatkan nilai $Y$ sebesar 0,868 .

\section{E. KESIMPULAN}

Terdapat hubungan yang kuat antara variabel penelitian pelayanan dan variabel kepuasan sebesar 0,766.

Berdasarkan hasil uji koefisien determinasi yang menyatakan bahwa pelayanan mempengaruhi kepuasan pelanggan sebesar $58,7 \%$ dan sisanya sebesar $41,3 \%$ dipengaruhi oleh faktor lain seperti pemberitahuan promosi, tata ruang atau lay out, citra organisai dan budaya kerja organisasi.

Pelayanan yang diberikan pada jasa sevice motor di CV Jaya Motor dirasakan telah optimal sesuai dengan persepsi kepuasaan pelanggan dengan nilai persamaan regresi $Y=8,630$ $+0,868(X)$.

Berdasarkan kesimpulan di atas terdapat beberapa saran dari penulis yang dapat dipertimbangkan untuk meningkatkan kepuasan pealangga akan pelayanan service sepeda motor pada CV Jaya Motor Bekasi, diantaranya: 1. Sebaiknya karyawan dalam pelayanan service lebih cepat tanggap dalam menangani keluhan pelanggan, sehingga pelanggan tidak merasa kecewa saat service sepeda motor pada CV Jaya Motor Bekasi. 2. Selain pelayanan yang diberikan karyawan kepada pelanggan, sebaikya tidak lupa dengan kebersihan tata ruang dan kamar mandi yang bersih dan nyaman. Dan sebaiknya diruang tunggu disediakan minuman, koran dan televisi sehingga pelanggan tidak merasa bosan menunggu service sepeda motor. 3. Bagian pelayanan hendaknya selalu memperhatikan kualitas pelayanan yang diberikan seperti perhatian individual kepada pelanggan, memahami kebutuhan pelanggan dan bersedia memberikan pelayanan tanpa diminta karena hal tersebut dapat mempegaruhi mengenai kepuasan pelanggan. 4. Pelayanan dalam perusahaan sangat penting, sebaiknya CV Jaya Motor agar terus meningkatkan kinerja pelayanan service 
sepeda motor, seperti memberikan informasi yang berguna kepada pelanggan, memiliki pengetahuan atau keahlian yang handal dan memiliki kemampuan dalam pelayanan service sepeda motor demi terwujudnya kenyamanan serta kepuasan pelanggan

\section{DAFTAR PUSTAKA}

Daryanto, dan Ismanto Setyobudi. 2014. Konsumen dan Pelayanan Prima. Yogyakarta: Gava Media.

Fandy, Tjiptono. 2014. Pemasaran Jasa. Andi: Yogyakarta

Kotler, Keller, 2012, Marketing Management: 14 Edition, New Jersey: Prentice Hall, Pearson Hall, Pearson Education, Inc.

Lestari, Sri dan Slamet Heri Winarno.2018. Determinasi Kepuasan dan Loyalitas Pengguna Jasa Pendidikan Pada Kinderfield School Cabang Bekasi Jawa Barat. Jurnal Akuntansi dan Manajemen. Vol 14 No. 2

Oktiani, Nurvi dan lis Apriyanti. 2016. Analisis Pengaruh Kualitas Pelayanan Terhadap Upaya Peningkatan Kepuasan Pelanggan Pada Penguna Jasa PT Tiki JNE Cabang Depok. Widya Cipta 8.2.

Priyatno, Duwi. 2014. SPSS 22 Mengolah Data Terpraktis. Yogyakarta: CV Andi Offset.

Rangkuti, Freddy. 2017. Customer Care Excellence. Jakarta: PT Gramedia.

Sangadji, Etta Mamang, dan Sopiah. 2010. Metodologi Penelitian: Pendekatan Praktis dalam Penelitian. Yogyakarta: CV Andi Offset.

Santoso, Singgih. 2013. Menguasai SPSS 21 Di Era Informasi. Jakarta: PT Elex Media Komputindo.

Sugiyono. 2015. Metode Penelitian Kuantitatif Kualitatif dan R\&D. Bandung: Alfabeta.

Sunyoto, Danang. 2014. Konsep Dasar Riset Pemasaran Dan Perilaku Konsumen. Yogyakarta: CAPS (Center For Academic Publishing Service).

Tjiptono, Fandy dan Chandra Gregorius. 2012. Pemasaran Strategik Edisi 2. Yogyakarta: Andi.

Winarno, Slamet Heri, Bryan Givan dan Yudhistira. 2018. Determinan Loyalitas Pelanggan Operator Telepon Selular. Esensi: Jurnal Bisnis dan Manjemen. Vol. 8 No. 2

Windasuri, Heria, Hyacintha Susanti dan BusinessGrowth Team. 2017. ExcellentService. Jakarta: PT Gramedia Pustaka Utama. 